\title{
Parenteral nutrition use in children with cancer
}

Kathleen H McGrath, FRACP, MBBS, BSc (Med) ${ }^{1,2}$

${ }^{1}$ Department of Gastroenterology and Clinical Nutrition, The Royal Children's Hospital, Melbourne, Australia.

${ }^{2}$ Intestinal Failure and Clinical Nutrition Group, Murdoch Children's Research Institute, Melbourne, Australia.

Brief running title: Parenteral nutrition in children with cancer

Keywords: nutrition, nutritional support, paediatric oncology

\section{Word count:}

Abstract: 100

Main text: 3475

Tables: 3

Figures: 1

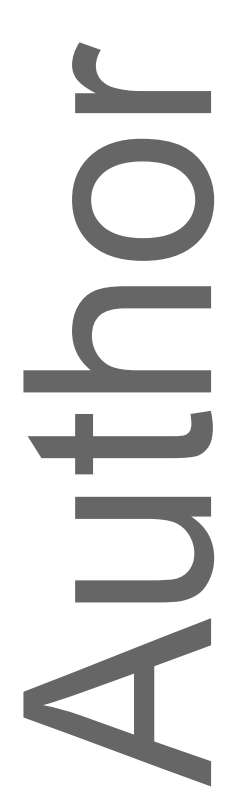

Abbreviations key:

\begin{tabular}{|l|l|}
\hline EN & Enteral nutrition \\
\hline HSCT & Haematopoietic stem cell transplant \\
\hline PN & Parenteral nutrition \\
\hline
\end{tabular}

\section{Corresponding Author:}

Dr Kathleen H McGrath, FRACP, MBBS, BSc (Med)

Department of Gastroenterology and Clinical Nutrition

Birmingham Children's Hospital,

This is the author manuscript accepted for publication and has undergone full peer review but has not been through the copyediting, typesetting, pagination and proofreading process, which may lead to differences between this version and the Version of Record. Please cite this article as doi: 10.1002/pbc.28000.

This article is protected by copyright. All rights reserved. 
Steelhouse Lane, Birmingham B4 6NH, United Kingdom

Telephone: +44756 3249769

Email: mcgrath.kathleen@gmail.com

\section{ABSTRACT}

Multiple disease and treatment-related factors contribute to intestinal insult and influence the nutritional status of children with cancer. Many children with cancer will experience intestinal dysfunction during their cancer journey and children with cancer are a common referral group for inpatient parenteral nutrition. Appropriate use of parenteral nutrition in children with cancer and intestinal failure may alleviate malnutrition and associated risks. However, proper selection of patients, correct parenteral nutrition prescription and close monitoring is important to avoid unnecessary intestinal failure or parenteral nutrition related complications, minimise long term nutritional sequelae or additional costs to health services and optimise intestinal rehabilitation.

\section{INTRODUCTION}

Despite advancement in survival outcomes for childhood cancer, ${ }^{1,2}$ the diagnosis and treatment of these conditions continues to be associated with significant nutritional burden.

All children with cancer are at risk of inadequate nutritional state or malnutrition, which may manifest as 'under-nutrition' (weight loss, inadequate weight gain or decreased fat free mass), 'over-nutrition' (excessive weight gain or increased proportion of body fat) or specific nutritional insufficiency (e.g. micronutrient deficiency).

The reported prevalence of malnutrition in children with cancer is $5.2 \%-48 \%^{3-6}$ and this may present at any stage during a patient's cancer journey from the time of diagnosis, throughout treatment and into survivorship. The impact of malnutrition varies in severity between individuals and can include detrimental consequences for critical childhood processes of 
growth, development and puberty. In children with cancer, malnutrition has been associated with poorer survival outcomes, increased morbidity, increased episodes of febrile neutropenia with bacteraemia and reduced physical, emotional and social functioning scores for health related quality of life. ${ }^{5,-11}$ Further, increased risk of long term health complications and comorbidities has been associated with malnutrition in childhood cancer survivors. ${ }^{12,13}$

Multiple disease and treatment-related factors may contribute to intestinal insult and influence the nutritional status of children with cancer. Chemotherapeutic agents and radiation therapy deplete the immunologically rich environment of the gastrointestinal tract and cause direct mucosal injury, which is further propagated by the production of reactive oxygen species and pro-inflammatory factors. ${ }^{14}$ Mucositis is a complex inflammatory condition of the mucous membranes which can affect any portion of the gastrointestinal tract and is commonly classified as oral or gastrointestinal mucositis. ${ }^{15}$ Chemotherapeutic agents may also directly alter absorptive and secretory functions of the intestinal villus-crypt unit and modify activity of brush border enzymes, which are essential to carbohydrate absorption pathways. Other layers of the intestinal wall may sustain damage from chemotherapeutic agents including cells of the lamina propria, musculature and enteric nervous system, resulting in intestinal dysmotility and predisposing to small intestinal bacterial overgrowth. ${ }^{16}$ Chemotherapy-induced immunosuppression and loss of mucosal barrier integrity increases the risk of secondary gastrointestinal infections (viral, bacterial, fungal, parasitic) which may further augment mucosal damage and lead to associated complications (e.g. pseudomembranous colitis).

Many children with cancer will experience intestinal dysfunction during their cancer journey, which may manifest as gastrointestinal symptoms (nausea, vomiting, diarrhoea, abdominal 
pain) and be associated with feed intolerance. Regular assessment and early identification of nutritional risk is important to facilitate timely intervention with nutritional support when indicated. Reduction in gut absorptive function that does not require intravenous supplementation to maintain health and / or growth can be termed 'intestinal insufficiency or deficiency' ${ }^{17}$ These children often require optimisation of dietary calories, oral nutritional supplements or enteral nutrition (EN) support to meet their energy requirements. EN has been shown to be an effective and well-tolerated method of feeding in children with cancer and those undergoing Haematopoietic Stem Cell Transplant (HSCT). ${ }^{18-22}$

Intestinal failure occurs when gut function falls below the minimum necessary for the absorption of macronutrients and / or water and electrolytes, and intravenous nutrition support may be required to meet energy, fluid and electrolyte requirements and prevent or correct malnutrition. ${ }^{17}$ Parenteral nutrition $(\mathrm{PN})$ is an intravenous solution containing macronutrients (protein, carbohydrate, fat) and micronutrients (vitamins and minerals), which is given through a catheter into a large vein to provide nutrition in children who cannot be fully fed by the oral or enteral route in order to sustain growth and prevent or correct malnutrition. PN should be reserved for children with significant gastrointestinal tract dysfunction and ongoing intolerance to advancement of enteral feeds or contraindication to oral or enteral feeding (e.g. gastrointestinal perforation or obstruction). For most patients, this period will be short-lived whilst the intestinal tract recovers from an insulting agent or event, however for some children with cancer, persistent intestinal failure may lead to requirement for long term inpatient $\mathrm{PN}$, which in clinical practice generally refers to a period of use greater than 4 to 6 weeks. 
This article provides a comprehensive critical review of current available literature on indications, use and management of short and long term PN in children with cancer. It highlights important considerations for all clinicians involved in managing children with cancer and intestinal failure to assist decision-making and facilitate appropriate patient selection, safe prescription and optimise monitoring practices and intestinal rehabilitation.

\section{METHODS}

A comprehensive literature review was performed in December 2018 of the following databases: Medline (Ovid) and Embase (Ovid). Thesaurus and/or keywords were used as follows: (exp "Neoplasm [MeSH term] AND "Parenteral nutrition"). Results were limited to English language and children 0-18 years of age. PubMed was searched using keywords only to retrieve E-publications and items not indexed in Medline. The Medline search strategy was adapted for use in other databases. Additional items were identified through hand-searching of reference lists of relevant retrieved articles.

\section{INDICATIONS AND BENEFITS OF PARENTERAL NUTRITION}

Children with cancer are a common referral group for inpatient PN with frequent indications including HSCT related secondary intestinal failure, cancer treatment induced feed intolerance and mucositis. $^{23}$

Timing of initiation of PN depends on the age, size and situation of the child. The wellnourished human body can tolerate short periods of inadequate nutrition for up to 3 days in infants and 5 days in an older child / adolescent whilst enteral feeding or oral diet is established. ${ }^{24}$ A large study of critically unwell children in intensive care showed superior clinical outcomes (acquisition of new infections, length of stay in intensive care) when PN 
was withheld for 1 week compared with early PN. ${ }^{25}$ In the presence of significant

malnutrition or weight loss with gastrointestinal tract dysfunction limiting enteral tolerance, PN may be indicated earlier and further research is needed to define optimal time of PN commencement in children with cancer. ${ }^{24}$

Quality data on specific risks and benefits of PN use in children with cancer is limited. A 2015 Cochrane review found limited evidence from individual trials to suggest PN is more effective for weight gain than EN in well-nourished children with cancer undergoing chemotherapy. However, this was based on a small number of low quality studies and they concluded that further research is needed. ${ }^{26}$ No conclusions were made regarding recommended mode of nutrition in children with cancer who are malnourished because of insufficient evidence and further studies are needed. ${ }^{26}$

A study of adults and children undergoing HSCT in 1984 reported engraftment three days earlier in patients given prophylactic PN compared with clinically indicated nutritional intervention however they concluded no overall clinical benefit based on other clinical outcomes. ${ }^{27}$ Another study a few years later concluded PN use had no beneficial effect on the time course of marrow recovery but favourable effects on weight gain. ${ }^{28}$ Nutritional innovation in recent decades including the development of elemental formulas and modern parenteral lipid formulations have changed nutritional management and hence results of earlier studies may not always be applicable to current practice. Further, clinical significance of weight gain post HSCT can be difficult to interpret due to the influence of other factors on fluid balance (e.g. medications and intravenous fluid therapy) and ideally, other nutritional parameters such as anthropometry should be performed and considered. 


\section{RISKS AND COMPLICATIONS OF PARENTERAL NUTRITION}

Complications associated with PN use in children with cancer can be classified as mechanical, metabolic or infection related and are summarised in Table 1. Cancer treatments 口 (2) may independently affect immune function, lipid and glucose metabolism and further increase risk of metabolic and infective complications when compared with children on PN without cancer. ${ }^{29,30} \mathrm{PN}$ has been identified as an independent risk factor for increased infection rate in children with cancer with a central venous access device. ${ }^{31}$ The precise mechanism for this association is unclear but is likely multifactorial (e.g. treatment associated mucosal barrier injury, immunosuppression, frequent use of central venous access device) rather than an isolated direct effect from PN alone. PN use has been associated with loss of appetite and may delay resumption of oral diet in children post HSCT. ${ }^{30}$

Refeeding syndrome is a constellation of metabolic disturbances and physiological changes related to administration of a caloric load (EN or PN) or rapid feeding in the presence of severe malnutrition or starvation. Insulin is secreted in response to glucose administration, which drives glucose entry into cells as well as potassium, phosphate and magnesium, leading to intravascular depletion of these electrolytes. Risk factors for refeeding syndrome include prolonged fasting ( $>5$ days), minimal nutritional intake for $>7$ days, weight loss $>$ $10 \%$ body weight and underlying eating disorder. ${ }^{24}$ Patients who require $\mathrm{PN}$ and are at risk of refeeding syndrome should have all electrolyte abnormalities corrected prior to commencement of PN and close monitoring including increased frequency of monitoring bloods (Table 2). Nutritional support should be graded up with caution and if significant electrolyte abnormalities develop, PN should be paused, intravenous fluids commenced 
(containing 5\% dextrose) and electrolyte abnormalities corrected prior to PN recommencement. $^{24}$

\section{PARENTERAL NUTRITION MONITORING AND OTHER INVESTIGATIONS}

All children with cancer receiving PN should have routine monitoring to assess for tolerance and identify complications (Table 2). ${ }^{24}$ Results should be used to provide individual patient recommendations and modifications to the PN prescription as indicated.

Children with cancer with protracted intestinal failure requiring long term inpatient PN require additional monitoring and assessment of nutritional status. This may include assessment of micronutrient status such as fat soluble vitamins (e.g. Vitamin A, Vitamin D, and Vitamin E), water soluble vitamins (e.g. Vitamin B12, folate) and trace elements (e.g. iron, zinc, copper, selenium). Accurate assessment of some micronutrients may be hindered by the presence of acute inflammation or frequent blood transfusions and individual patient circumstances should be considered when ordering and interpreting these tests.

Various biomarkers for intestinal function have been proposed for use in children with cancer undergoing chemotherapy to aid clinical assessment of degree of intestinal dysfunction and monitor stages of repair. Although biomarkers hold promise for early identification of intestinal mucositis and possible intervention (e.g. timely placement of nasogastric tube prior to onset of severe mucositis or cytopenias), none of these tests are without limitation. They remain largely research based and inaccessible to most clinicians in clinical practice and are summarised briefly below. ${ }^{16,32}$ 
Sugar permeability tests (D-Xylose, lactulose/rhamnose and lactulose/mannitol ratio) have been used as markers for loss of barrier function but are complicated to perform and thus not practical in the clinical setting especially for children. ${ }^{32}$ Plasma citrulline is a non-essential amino acid produced from glutamine in enterocytes which can be used as a marker of 口 functional small intestinal mucosal mass to reflect absorptive capacity. Low levels have been shown to correspond with severe mucosal barrier injury in patients undergoing HSCT. ${ }^{14,32,33}$ Isolated citrulline levels may have a role in differentiating site of gastrointestinal inflammation (small versus large bowel) in the absence of endoscopy and serial measurements can be used to monitor trends of cumulative small intestinal damage and progressive intestinal recovery / adaptation. ${ }^{14}$ Breath tests such as the ${ }^{13} \mathrm{C}$ sucrose test measure expired breath $13 \mathrm{CO} 2$ to reflect enterocyte absorptive digestive enzyme function, following ingestion of a sucrose load that is digested in the intestine and metabolised in the liver. A decreased amount of expired $13 \mathrm{CO} 2$ occurs in the presence of gastrointestinal tract damage. ${ }^{32}$ Other proteins such as intestinal fatty acid binding protein (I-FABP) and ileal bile acid binding protein (I-BABP) have been proposed as biomarkers but require further research to determine their exact role and practicality for clinical use. ${ }^{16,32}$

\section{PRINCIPLES OF MANAGEMENT IN CHILDREN WITH CANCER AND}

\section{INTESTINAL FAILURE}

Management of children with cancer and intestinal failure who require inpatient PN should address three key areas: (1) removal of factors precipitating or contributing to intestinal dysfunction where possible, (2) supportive care for gastrointestinal symptoms and (3) nutritional assessment and support as indicated to alleviate malnutrition, with close monitoring to avoid intestinal failure or PN related complications. 


\section{$\underline{\text { Removal of precipitating or contributing factors }}$}

Precipitating factors should be removed and differential causes for intestinal dysfunction identified and treated where possible e.g. secondary gastrointestinal infections, cessation or dose reduction of implicated drugs. In patients undergoing HSCT, specific inflammatory and immunological processes within the gastrointestinal tract should be considered and are summarised in Table $3 .^{34}$

\section{$\underline{\text { Supportive care for symptoms }}$}

Accurate assessment and documentation of fluid balance in the medical record is essential to guide decision making on appropriateness of PN indication and monitoring ongoing progress. Information recorded should include daily weight, frequency and size and nature of all gastrointestinal losses (stool, vomit, other), urine output and all intake volumes (oral / enteral / parenteral).

Management of diarrhoea and vomiting requires careful attention to fluid balance to monitor for dehydration and electrolyte imbalances. Literature on therapeutic options in children with chemotherapy induced diarrhoea is very limited. There is literature to support the use of loperamide or octreotide for management of persistent diarrhoea in adults with cancer (once infectious causes have been excluded) ${ }^{15,35}$ and oral antibiotics are recommended for adults with cancer with greater than 24 hours of chemotherapy induced diarrhoea to prevent septic complications. ${ }^{36}$ The relevance of these findings to management of diarrhoea in children is unclear and there is a need for future research.

Management of other common gastrointestinal symptoms including abdominal pain, nausea and vomiting should follow specific management guidelines of the treating unit and aim to 
minimise the impact of these symptoms on the patient and optimise their capacity for oral and enteral nutritional intake.

\section{$\underline{\text { Nutritional assessment }}$}

Traditional anthropometric measures (weight, height and body mass index) in children with cancer may not differ from healthy age matched controls despite significant loss of body cell mass and increase in fat mass, potentially leading to inaccurate nutritional assessment. ${ }^{6,37}$ Weight may be affected by multiple factors including tumour growth or shrinkage, changes in fluid status (hyper hydration or dehydration) or medication use (e.g. steroid induced fluid retention or diuretic use) and evolving malnutrition may be masked. Optimal techniques for routine nutritional assessment in children with cancer are unclear, however use of alternative anthropometry measurements (e.g. triceps skin fold, mid upper arm circumference) are recommended when possible in conjunction with traditional measures. ${ }^{11}$

\section{Nutritional support}

EN is recommended as the nutritional strategy of choice in all patients with a functional gastrointestinal tract. ${ }^{32,38-41}$ It provides essential trophic factors to maintain gastrointestinal mucosa $\mathrm{a}^{31,42}$ and when compared to PN, has been shown to have lower infection rates, less requirement for monitoring bloods, less cost and can be easily administered as an outpatient. $^{29,38,40,43-45}$ Animal models of gastrointestinal mucositis show glucose and amino acids are still absorbed during active inflammation when administered continuously, however lactose and fatty acids are not and use of an elementary, lactose free formula with reduced long chain triglycerides given continuously via enteral feeding tube may maximise chances of absorption and enteral tolerance in children with cancer. ${ }^{15}$ In clinical practice, peptide based or semi-elemental formulas are commonly recommended as initial feed choice when enteral 
feeding is indicated and the patient tolerance is assessed by close nutritional follow up. A recent Cochrane systematic review found no statistically significant evidence to support reduction in severity of mucositis or infection with glutamine supplementation, however only 2 studies were included. ${ }^{26}$

When appropriately indicated, PN prescription in children with cancer should involve an experienced dietitian to determine specific targets for energy and protein requirements.

Macronutrient requirements differ depending on age, baseline nutritional state and clinical situation and whilst an age-appropriate balance of carbohydrate, protein and fat should be maintained where possible, metabolic changes in children with cancer may alter the way substrates are utilised and influence individual needs. Further, accessibility of individualised rather than standard hospital solutions of PN may differ between individual centres and influence ability and duration to meet target macronutrient requirements.

Excessive provision of calories should be avoided. Adequate protein is critical to counteract catabolic effects of cancer on muscle and immune function. Hyperglycemia may be encountered and is commonly multifactorial, related not only to PN use, but steroids, transient insulin resistance and other factors. The glucose content of PN may require modification and consideration should be given to the role for insulin therapy if hyperglycemia persists despite changes to modifiable factors. Children with cancer on long term PN may have periods where they are prescribed fat-free PN in the context of high triglyceride levels. When this occurs alongside minimal oral intake, there may be risk of essential fatty acid deficiency. Abnormal essential fatty acid profiles have been documented in patients undergoing HSCT. ${ }^{46}$ Fat intake should be independently assessed to ensure the minimum recommended dosage is administered to prevent essential fatty acid deficiency $(0.1 \mathrm{~g} / \mathrm{kg} / \text { day })^{47}$ 
Measures should be taken to minimise risk of intestinal failure associated liver disease (IFALD). These include avoiding excessive PN caloric intake, consideration of PN cycling (providing hours off infusion) and administration of trophic feeds, which are small volumes of feed provided continuously into the gastrointestinal tract by enteral feeding tube to help maintain the integrity of the gastrointestinal tract. ${ }^{42}$ When a patient does not have a nasogastric tube in place to provide trophic EN and they are safe to receive small volumes of feed, the benefits should be discussed with the patient and family and nasogastric tube insertion considered at the first suitable opportunity.

Carnitine is a micronutrient with an important role in fatty acid metabolism and energy production in muscle. Children with cancer have risk factors for carnitine deficiency (decreased oral intake, increased metabolic requirements, interference with metabolism / excretion by certain chemotherapy agents (cisplatin, ifosfamide, doxorubicin)) and carnitine deficiency has been studied as a potential contributor to cancer-related fatigue however the role of supplementation remains unclear and there are few studies in children. ${ }^{48-49}$

The role of the microbiome in intestinal damage and dysfunction in children with cancer is an emerging area of research. Alterations in the microbiome have been documented in patients undergoing HSCT and associated with adverse transplant outcomes. ${ }^{50}$ Multiple influencing factors have been proposed including use of prophylactic antibiotics, neutropenic diet and PN. Future research in children undergoing HSCT will help to elucidate the role of microbiome assessment and management. 


\section{DISCUSSION}

The challenges inherent to performing quality research in paediatric nutrition are present in many of the existing published studies related to PN use in children with cancer. Many studies are retrospective and assess heterogeneous populations with different diagnoses at variable times during treatment or diagnosis with variation evident in methods of nutritional assessment and diagnostic criteria for malnutrition. These limitations influence the capacity to compare studies and extrapolate findings to clinical settings. This review provides a summary of current literature on PN use in children with cancer but demonstrates the need for future large prospective studies assessing nutritional management in children with different types of cancer. Future research is needed to help define the role and outcomes for different forms of nutrition support in this high nutritional risk population and to develop clinical tools to aid clinician and patient decision making.

Children with cancer have multiple risk factors for gastrointestinal insult and nutritional compromise is common. In clinical practice, determining the degree of intestinal dysfunction can be challenging for clinicians and there may uncertainty about which patients are appropriate for PN use and when to refer. This paper highlights the paucity of current literature or published indications to guide clinicians in decision making and the clear need for further research in this area. Use of PN in children with cancer should be judicious and PN should be reserved for children with significant gastrointestinal tract dysfunction and ongoing intolerance to advancement of enteral feeds or contraindication to oral or enteral feeding. With supportive intestinal rehabilitation, most children with cancer will successfully be able to grade up on oral diet or EN and wean PN within a few weeks. Regular reassessment of enteral tolerance and capacity to wean and cease PN is important to avoid 
unnecessary delay in PN wean and cessation and undue burden of prolonged hospitalisation (for patients and families), PN associated complications (for patients) or cost (for hospitals).

All children with cancer who require long term inpatient PN should have a trained paediatric nutrition support team actively involved in their ongoing care and have unique management considerations (Fig. 1). An active approach towards intestinal rehabilitation is important and emerging areas of research such as the role of the microbiome in intestinal dysfunction may provide future avenues for targeted treatment. Home PN for children with cancer is institution dependent and is uncommon. When available, it requires careful assessment of the family and child's suitability for the service, including consideration of the significant burden of care and availability of appropriate home nursing support services.

When indicated, the use of PN in children with cancer and intestinal failure may alleviate malnutrition and associated risks. However, appropriate selection of patients, correct PN prescription and close monitoring is important to avoid unnecessary complications associated with intestinal failure or PN, optimise intestinal rehabilitation, minimise long term nutritional sequelae and additional costs to health services.

Conflicts of interest: None

Acknowledgements: Dr Jason Yap, Dr Julie Bines, Prof Winita Hardikar 


\section{References}

${ }^{1}$ Birch JM, Marsden HB, Morris Jones PH, Pearson D, Blair V. Improvements in survival from childhood cancer: results of a population based survey over 30 years. Br Med J (Clin Res Ed). 1988;296:1372.

${ }^{2}$ Gatta G, Botta L, Rossi S, Aareleid T, Bielska-Lasota M, Clavel J et al. Childhood cancer survival in Europe 1999-2007: results of EUROCARE-5- a population-based study. Lancet Oncol. 2014;15(1):35-47.

${ }^{3}$ Brinksma A, Roodbol PF, Sulkers E, Kamps WA, de Bont ESJM, Boot AM, Burgerhof JGM, Tamminga RYJ, Tissing WJE. Changes in nutritional status in childhood cancer patients: A prospective cohort study. Clin Nut. 2015;34:66-73.

${ }^{4}$ Galati PC, Resende CMM, Salomao RG, Scridelli CA, Tone LG, Monteiro JP. Accurate determination of energy needs in children and adolescents with cancer. Nutr Cancer. 2011;63(2):306-313.

${ }^{5}$ Loeffen EAH, Brinksma A, Miedema KGE, de Bock GH, Tissing WJE. Clinical implications of malnutrition in childhood cancer patients- infections and mortality. Support Care Cancer. 2015;23:143-150.

${ }^{6}$ Murphy AJ, White M, Elliott SA, Lockwood L, Hallahan A and Davies PSW. Body composition of children with cancer during treatment and in survivorship. Am J Clin Nutr. 2015;102:891-896.

${ }^{7}$ Brinksma A, Sanderman R, Roodbol PF, Sulkers E, Burgerhof JGM, de Bont ESJM, Tissing WJE. Malnutrition is associated with worse health-related quality of life in children with cancer. Support Care Cancer. 2015;23:3043-3052.

${ }^{8}$ Butturini AM, Dorey FJ, Lange BJ et al. Obesity and outcome in pediatric acute lymphoblastic leukemia. J Clin Oncol. 2007;25(15):2063-2069.

${ }^{9}$ Lobato-Mendizabal E, Lopez-Martinez B, Ruiz-Arguelles GJ. A critical review of the prognostic value of the nutritional status at diagnosis in the outcome of therapy of children with acute lymphoblastic leukemia. Rev Invest Clin. 2003;55(1):31-35.

${ }^{10}$ Orgel E, Sposto R, Malvar J, Seibel NL, Ladas E, Gaynon PS, Freyer DR. Impact on survival and toxicity by duration of weight extremes during treatment for pediatric acute lymphoblastic leukemia: A report from the Children's Oncology Group. J Clin Oncol. 2014;32:1331-1337. 
${ }^{11}$ Sala A, Rossi E, Antillon F, Molina AL, de Maselli T, Bonilla M, Hernandez A, Ortiz R, Pacheco C, Nieves R, Navarrete M, Barrantes M, Pencharz P, Valsecchi MG, Barr R.

Nutritional status at diagnosis is related to clinical outcomes in children and adolescents with cancer: A perspective from Central America. Eur J Cancer. 2012;48:243-252.

${ }^{12}$ Armstrong GT, Oeffinger KC, Chen Y, Kawashima T, Yasui Y, Leisenring W, Stovall M, Chow EJ, Sklar CS, Mulrooney DA et al. Modifiable risk factors and major cardiac events among adult survivors of childhood cancer. J Clin Oncol. 2013;31:3673-3680.

${ }^{13}$ Nolan CG, Krull KR, Gurney JG, Leisenring W, Robison LL, Ness KK. Predictors of future health-related quality of life in survivors of adolescent cancer. Pediatr Blood Cancer. 2014;61:1891-1894.

${ }^{14}$ Gosselin KB, Feldman HA, Sonis AL, Bechard LJ, Kellogg MD, Gura K, Venick R, Gordon CM, Guinan EC, Duggan C. Serum citrulline as a biomarker of gastrointestinal function during hematopoietic cell transplantation in children. J Pediatr Gastroenterol Nutr. 2014;58(6):709-714.

${ }^{15}$ Kuiken NSS, Rings EHHM, Tissing WJE. Risk analysis, diagnosis and management of gastrointestinal mucositis in pediatric cancer patients. Crit Rev Oncol Hematol. 2015;94:8797.

${ }^{16}$ Butler RN. Measuring tools for gastrointestinal toxicity. Curr Opin Support Palliat. 2008;2:35-39.

${ }^{17}$ Pironi L, Arends J, Baxter J, et al. ESPEN endorsed recommendations. Definition and classification of intestinal failure in adults. Clin Nutr. 2015;34(2):171-180.

${ }^{18}$ Azarnoush S, Bruno B, Beghin L, Guimber D, Nelken B, Yakoub-Agha I, Seguy D. Enteral nutrition: a first option for nutritional support of children following allo-SCT? Bone Marrow Transplant. 2012;47(9):1191-1195. 
${ }^{19}$ Bicakli DH, Yilmaz MC, Aksoylar S, Kantar M, Cetingul N, Kansoy S. Enteral nutrition is feasible in pediatric stem cell transplantation patients. Pediatr Blood Cancer.

2012;59(7):1327-1329.

${ }^{0}$ Hastings Y, White M, Young J. Enteral nutrition and bone marrow transplantation. J Pediatr Oncol Nurs. 2006;23(2):103-110.

${ }^{21}$ Langdana A, Tully N, Molloy E, Bourke B, O’Meara A. Intensive enteral nutrition support in paediatric bone marrow transplantation. Bone Marrow Transplant. 2001;27:741-746.

${ }^{22}$ Szeluga DJ, Stuart RK, Brookmeyer R, Utermohlen V, Santos GW. Nutritional support of bone marrow transplant recipients: A prospective, randomised clinical trial comparing total parenteral nutrition to an enteral feeding program. Cancer Res. 1987;47:3309-3316.

${ }^{23}$ Mantegazza C, Landy N, Hill SM, Zuccotti GV, Kuglmeier J. Parenteral nutrition in hospitalised children. Med Clin Rev. 2016;2(1:4):1-7.

${ }^{24}$ Clinical nutrition program team, The Royal Children's Hospital, ed. Practical paediatric nutrition support. $2^{\text {nd }}$ Edition. Melbourne, Victoria: Department of Gastroenterology and Clinical Nutrition, The Royal Children's Hospital; 2014.

${ }^{25}$ Fivez T, Kerklaan D, Mesotten D, Verbruggen S, Wouters PJ, Vanhorebeek I et al. Early versus late parenteral nutrition in critically ill children. N Engl J Med. 2016;374:1111-1122.

${ }^{26}$ Ward EJ, Henry LM, Friend AJ, Wilkins S, Phillips RS. Nutritional support in children and young people with cancer undergoing chemotherapy. Cochrane Database Syst Rev. 2015 Aug 24;(8):CD003298. Doi 10.1002/14651858.

${ }^{27}$ Weisdorf S, Hofland C, sharp HL, Teasley K, Schissel K, McGlave PB, Ramsay N, Kersey J. Total parenteral nutrition in bone marrow transplantation: A clinical evaluation. J Pediatr Gastroenterol Nutr. 1984;3:95-100. 
${ }^{28}$ Yokoyama S, Fukimoto T, Mitomi T, Yabe M, Yabe H, Kato S. Use of parenteral nutrition in pediatric bone marrow transplantation. Nutrition. 1989;5(1):27-30.

${ }^{29}$ Steele C, Salazar A, Rypkema L. Utilization of a Nutrition Support Algorithm Reduces Unnecesary Parenteral Nutrition Use in Pediatric Oncology Inpatients. J Acad Nutr Diet. $\square$ 2016;116(8):1235-1238.

${ }^{30}$ Charuhas PM, Fosberg KL, Bruemmer B, Aker SN, Leisenring W, Seidel K, Sullivan KM. A double-blind randomised trial comparing outpatient parenteral nutrition with intravenous hydration: Effect on resumption of oral intake after marrow transplantation. J Parenter Enteral Nutr. 1997;21:157-161.

${ }^{31}$ Christensen ML, Hancock ML, Gattuso J, Hurwitz CA, Smith C, McCormick J, Mirro J. Parenteral nutrition associated with increased infection rate in children with cancer. Cancer. $1993 ; 72: 2732-2738$.

${ }^{32}$ Kuiken NSS, Rings EHHM, Blijlevens NMA, Tissing WJE. Biomarkers and non-invasive tests for gastrointestinal mucositis. Support Care Cancer. 2017;25(9):2933-2941.

${ }^{33}$ Goulet O, Ruemmele F, Lacaille F, Colomb V. Irreversible intestinal failure. J Pediatr Gastroenterol Nutr. 2004;38:250-269.

${ }^{34}$ Lee J-H, Lim G-Y, Im SA, Chung N-G and Hahn S-T. Gastrointestinal complications following haematopoietic stem cell transplantation in children. Korean J Radiol. 2008;9:449457.

${ }^{35}$ Koselke EA, Kraft S. Chemotherapy-induced diarrhoea: Options for treatment and prevention. J Hematol Oncol Pharm. 2012;2(4).

${ }^{36}$ Benson AB $3{ }^{\text {rd }}$, Ajani JA, Catalano RB, Engelking C, Kornblau SM, Martenson JA Jr, McCallum R, Mitchell EP, O’Dorisio TM, Vokes EE, Wadler S. Recommended guidelines for the treatment of chemotherapy induced diarrhoea. J Clin Oncol. 2004;22:2918-2926. 
${ }^{37}$ Murphy AJ, White M, Davies PSW. Body composition of children with cancer. Am J Clin Nutr. 2010;92:55-60.

${ }^{38}$ De Swarte-Wallace J, Firouzbakhsh S, Finklestein JZ. Using research to change practice: enteral feedings for pediatric oncology patients. J Pediatr Oncol Nurs. 2001;18(5):217-223.

${ }^{39}$ Ladas, E. J., N. Sacks, Meacham L, Henry D, Enriquez L, Lowry G, Hawkes R, Dadd G, Rogers P. A multidisciplinary review of nutrition considerations in the pediatric oncology population: a perspective from children's oncology group. Nutr Clin Pract. 2005;20 (4): 377-393.

${ }^{40}$ Pietsch JB, Ford C, Whitlock JA. Nasogastric tube feedings in children with high-risk cancer: A pilot study. J Pediatr Hematol Oncol. 1999;21(2):111-114.

${ }^{41}$ Trimpe K, Shaw MR, Wilson M, Haberman MR. Review of the effectiveness of enteral feeding in pediatric oncology patients. J Pediatr Oncol Nurs. 2017;34(6):439-445.

${ }^{42}$ Ohta K, Omura K, Hirano K, Kanehira E, Ishikawa N, Kato Y, Kawakami K, Watanabe G. The effects of an additive small amount of a low residue diet against total parenteral nutrition-induced gut mucosal barrier. Am J Surg. 2003;185:79-85.

${ }^{43}$ Guieze R, Lemal R, Cabrespine A, Hermet E, Tournhilac O, Combal C, ...Bouteloup C. Enteral versus parenteral nutrition support in allogenic haematopoietic stem-cell transplantation. Clin Nut. 2014;33(3):533-538.

${ }^{44}$ Aquino VM, Smyrl CB, Hagg R, McHard KM, Prestridge L, Sandler ES. Enteral nutrition support by gastrostomy tube in children with cancer. J Pediatr. 1995;127(1):58-62.

${ }^{45}$ Bisgaard Pedersen AM, Kok K, Peterson G, Nielsen OH, Michaelsen KF, Schmiegelow K. Percutaneous endoscopic gastrostomy in children with cancer. Acta Paediatr. 1999;88:849852. 
${ }^{46}$ Clemens GW, Yamanaka W, Flournoy N, Aker SN, Thomas ED, Hutchinson ML, Cheney C. Plasma fatty acid patterns of bone marrow transplant patients primarily supported by fatfree parenteral nutrition. J Parenter Enteral Nutr. 1981;5(3):221-225.

Lapillonne A, Fidler Mis N, Goulet O, van den Akker CHP, Wu J, Koletzko B and the ESPGHAN/ESPEN/ESPR/CSPEN working group on pediatric parenteral nutrition.

ESPGHAN / ESPEN / ESPR / CSPEN guidelines on pediatric parenteral nutrition: Lipids.

Clin Nut. 2018;37:2324-2336.

${ }^{48}$ Hockenberry MJ, Hooke MC, Gregurich M, McCarthy K. Carnitine plasma levels and fatigue in children / adolescents receiving cisplatin, ifosfamide, or doxorubicin. J Pediatr Hematol Oncol. 2009;31(9):664-669.

${ }^{49}$ Marx W, Teleni L, Opie RS, Kelly J, Marshall S, Itsiopoulos C, Isenring E. Efficacy and effectiveness of carnitine supplementation for cancer-related fatigue. A systematic literature review and meta-analysis. Nutrients. 2017;9(11):1224.

${ }^{50}$ Andermann TM, Peled JU, Ho C, Reddy P, Riches M, Storb R et al. The microbiome and haematopoietic cell transplantation: past, present, future. Biol Blood Marrow Transplant. 2018;24:1322-1340.

\section{Legend of Figures}

\section{Figure 1}

$$
\begin{aligned}
& \text { Summary of important considerations for } \\
& \text { clinicians involved in management of } \\
& \text { children with cancer requiring long term } \\
& \text { inpatient parenteral nutrition. }
\end{aligned}
$$




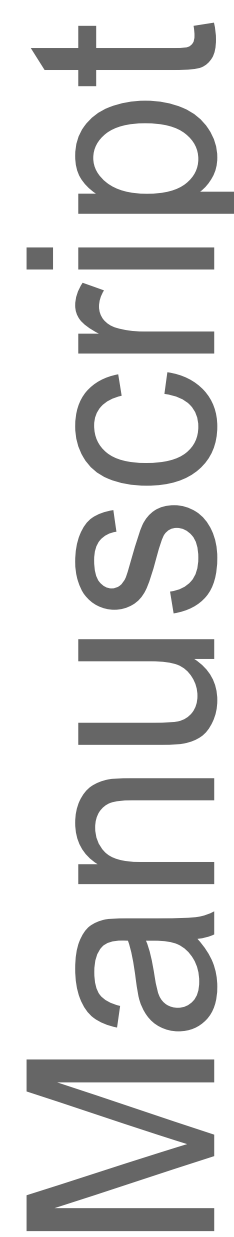

Child with cancer receiving Parenteral Nutrition for greater than 4 weeks?

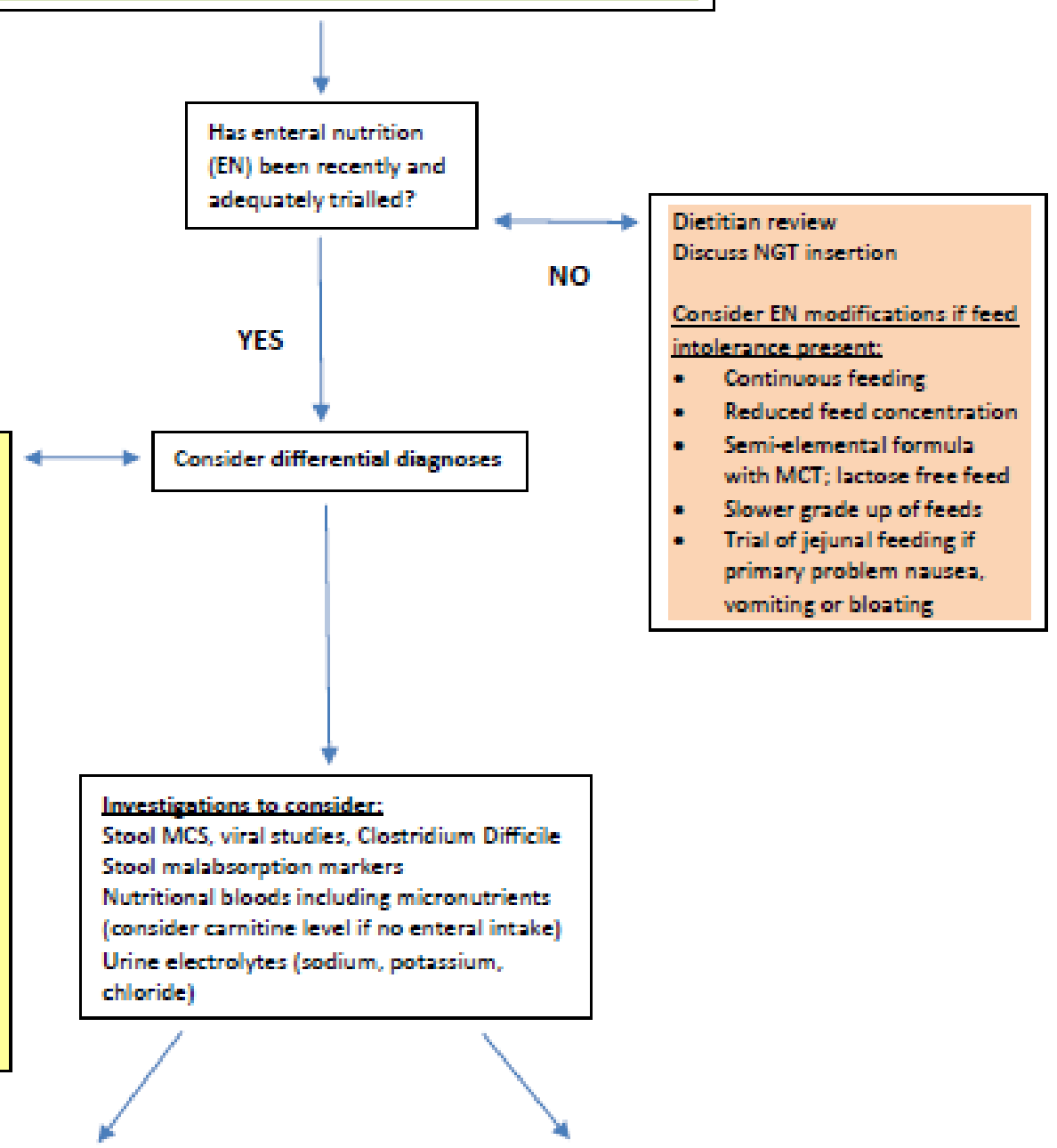
(typhilitis)

- Medication-related (Mycophenolate mofetil, cyclosporine, antibiotics, electrolyte supplements)

- Pancreatitis or pancreatic insufficiency

- Small intestinal bacterial overgrowth

- Surgical causes

- Post-transplant lymphoproliferative disease

\section{Non-nutritional manasement:}

- Strict fluid balance (daily weight, document all GI losses]

- Optimise supportive care for sastrointestinal symptoms

- Consider replacement of gastrointestinal locses $>20 \mathrm{~m} / / \mathrm{kg} / \mathrm{day}$

- Identify precipitating agents (e.g. medications, diet) and minimise if possible

- Consider pharmacological agents: prokinetics, loperamide, antibiotics
Nutritional support and monitoring:

Cycle PN when possible

- Avoid excessive provision of calories (review energy requirements and growth)

- Consider trophic feeds

- Ensure adequate lipid intake

- Liaise with Dietitian Slow controlled grade up of feeds and wean of parenteral nutrition if tolerated 
TABLE 1 Parenteral nutrition related complications.

\begin{tabular}{|c|c|c|c|}
\hline & $\begin{array}{l}\text { Mechanical } \\
\text { or equipment }\end{array}$ & Infective & Metabolic \\
\hline$\square$ & $\begin{array}{ll}\text { - } & \text { CVAD thrombosis } \\
\text { - } & \text { CVAD break occlusion } \\
\text { - } & \text { Accidental } \\
\text { - } & \text { dislodgement CVAD } \\
\text { Parenteral nutrition } \\
\text { pump malfunction }\end{array}$ & $\begin{array}{ll}\text { - } & \text { CVAD associated } \\
\text { bloodstream infection } \\
\text { - } & \text { CVAD site infection } \\
\text { - } & \text { CVAD tunnel infection }\end{array}$ & $\begin{array}{l}\text { Deficiency or excess of } \\
\text { individual parenteral } \\
\text { nutrition components e.g. } \\
\text { hypertriglyceridemia, } \\
\text { hyperglycaemia } \\
\text { - } \quad \text { Acid-base imbalance } \\
\text { - } \quad \text { Electrolyte derangement } \\
\text { - } \quad \text { Drug interaction or } \\
\text { - } \quad \text { Intestinal failure associated } \\
\text { - } \quad \text { Refeeding disease } \\
\text { - } \quad \text { Bone disease }\end{array}$ \\
\hline
\end{tabular}

CVAD; central venous access device

TABLE 2 Suggested monitoring tests for children with cancer on inpatient parenteral nutrition. ${ }^{24}$

\begin{tabular}{|c|c|c|c|}
\hline \multirow[t]{2}{*}{ Timing of investigation } & \multicolumn{3}{|c|}{ Monitoring test } \\
\hline & Blood & Urine & Other \\
\hline $\begin{array}{l}\text { Baseline (prior to PN } \\
\text { commencement) }\end{array}$ & $\begin{array}{l}\text { Serum electrolytes, urea, } \\
\text { creatinine, glucose, } \\
\text { calcium, phosphate, } \\
\text { magnesium, triglyceride } \\
\text { level, full blood count, } \\
\text { venous blood gas. } \\
\text { Consider micronutrient } \\
\text { deficiencies if clinically } \\
\text { indicated. }\end{array}$ & Urinalysis & $\begin{array}{l}\text { Weight } \\
\text { Height } \\
\text { Head circumference (for } \\
\text { children less than } 2 \text { years } \\
\text { old) }\end{array}$ \\
\hline $\begin{array}{l}\text { Daily for first 3-5 days on } \\
\text { PN or until stable on full } \\
\text { PN }\end{array}$ & $\begin{array}{l}\text { Serum electrolytes, urea, } \\
\text { creatinine, glucose, } \\
\text { calcium, phosphate, } \\
\text { magnesium, triglyceride } \\
\text { level. } \\
\text { Note- patients at high } \\
\text { risk of refeeding } \\
\text { syndrome may require 6- } \\
8 \text { hourly serum } \\
\text { electrolytes, urea, } \\
\text { creatinine, glucose, } \\
\text { calcium, phosphate and } \\
\text { magnesium in addition to } \\
\text { standard monitoring } \\
\text { bloods (for } 24-72 \text { hours } \\
\text { or as recommended by } \\
\text { local nutrition support } \\
\text { team). }\end{array}$ & Urinalysis & Daily weight \\
\hline
\end{tabular}

This article is protected by copyright. All rights reserved. 


\begin{tabular}{|l|l|l|l|}
\hline \begin{tabular}{|l|l|l|} 
Weekly monitoring once \\
stable on short term PN \\
(or as clinically indicated)
\end{tabular} & $\begin{array}{l}\text { Serum electrolytes, urea, } \\
\text { creatinine, glucose, } \\
\text { calcium, phosphate, } \\
\text { magnesium, triglyceride } \\
\text { level, full blood count, } \\
\text { venous blood gas. }\end{array}$ & $\begin{array}{l}\text { Urinalysis } \\
\text { Urine electrolytes } \\
\text { (sodium, potassium, } \\
\text { chloride) }\end{array}$ & $\begin{array}{l}\text { Regular weight (at least } \\
\text { twice weekly) }\end{array}$ \\
\\
$\begin{array}{llll}\text { Consider micronutrient } \\
\text { deficiencies if clinically } \\
\text { indicated. }\end{array}$ & & \\
\hline
\end{tabular}

$\mathrm{PN}$; parenteral nutrition

TABLE 3 Mechanisms of intestinal injury and differential diagnoses to consider in children following Haematopoietic stem cell transplant. ${ }^{34}$

\begin{tabular}{|c|c|c|c|}
\hline \multirow{2}{*}{$\begin{array}{l}\text { Feature of } \\
\text { intestinal } \\
\text { injury }\end{array}$} & \multicolumn{3}{|c|}{ Timing Post HSCT } \\
\hline & $\begin{array}{l}\text { Pre-engraftment phase } \\
\text { (usually between day } 0 \text { to day } \\
14-30 \text { post HSCT) }\end{array}$ & $\begin{array}{l}\text { Early post-engraftment phase } \\
\text { (day 30-100 post HSCT) }\end{array}$ & $\begin{array}{l}\text { Late post-engraftment } \\
\text { phase } \\
\text { (>day } 100 \text { post } \mathrm{HSCT})\end{array}$ \\
\hline Mechanisms & $\begin{array}{ll}\text { - } & \text { Immunosuppression } \\
\text { - } & \text { (neutrow aplasia } \\
\text { - } & \text { Cancer treatment related } \\
& \text { gastrotoxicity } \\
& \text { (chemotherapy, } \\
& \text { radiotherapy) } \\
\text { - } & \text { Medication side effects } \\
\text { - } & \text { Gastrointestinal dysbiosis } \\
\end{array}$ & $\begin{array}{l}\text { - } \quad \text { Immunosuppression } \\
\text { - } \quad \text { immullular and humoral } \\
\text { (lymphocytes) } \\
\text { - } \quad \text { Graft versus Host disease } \\
\text { - } \quad \text { Medication side effects } \\
\text { - } \quad \text { Gastrointestinal dysbiosis }\end{array}$ & $\begin{array}{ll}\text { - } & \text { Immunosuppression } \\
\text { - } & \text { Presence of Epstein } \\
\text { - } & \text { Barr Virus infection } \\
& \text { Graft versus Host } \\
\text { disease }\end{array}$ \\
\hline $\begin{array}{l}\text { Differential } \\
\text { diagnoses }\end{array}$ & 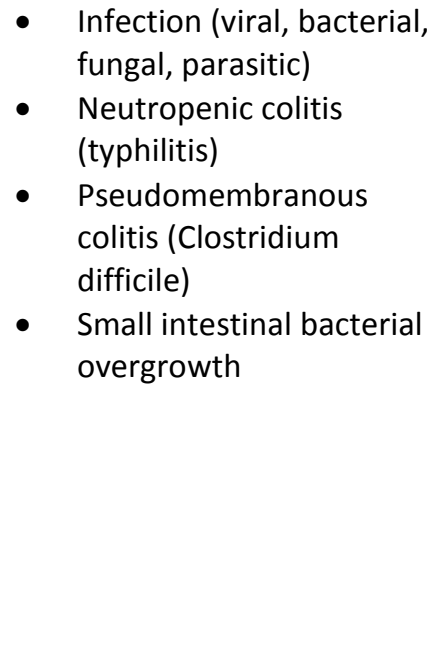 & $\begin{array}{ll}\text { - } & \text { Viral enteritis } \\
& \text { (Cytomegalovirus } \\
& \text { gastroenteritis) } \\
\text { - } & \text { Other infection (bacterial, } \\
& \text { fungal, parasitic) } \\
\text { - } & \text { Graft versus Host disease } \\
& \text { (acute) } \\
\text { - } & \text { Pneumatosis Intestinalis } \\
\text { - } & \text { Thrombotic } \\
& \text { microangiopathy after } \\
& \text { Transplantation } \\
\text { - } & \text { Megacolon } \\
\text { - } & \text { Cord colitis } \\
\text { - } & \text { Small intestinal bacterial } \\
& \text { overgrowth }\end{array}$ & $\begin{array}{l}\text { - Infection (viral, } \\
\text { bacterial, fungal, } \\
\text { parasitic) } \\
\text { - } \quad \text { Post-Transplantation } \\
\text { Lymphoproliferative } \\
\text { Disease } \\
\text { - } \begin{array}{l}\text { Graft versus Host } \\
\text { disease (chronic) }\end{array}\end{array}$ \\
\hline
\end{tabular}

HSCT; Haematopoietic Stem Cell Transplant

This article is protected by copyright. All rights reserved. 


\section{University Library}

\section{- M M I N E R VA A gateway to Melbourne's research publications}

Minerva Access is the Institutional Repository of The University of Melbourne

Author/s:

McGrath, KH

Title:

Parenteral nutrition use in children with cancer

Date:

2019-09-18

Citation:

McGrath, K. H. (2019). Parenteral nutrition use in children with cancer. PEDIATRIC BLOOD \& CANCER, 66 (12), https://doi.org/10.1002/pbc.28000.

Persistent Link:

http://hdl.handle.net/11343/286428 